\title{
EXPLORING TEACHERS' BELIEFS ON TEACHING METHODOLOGY IN THE 2013 CURRICULUM AND THE APPLICATION IN LANGUAGE TEACHING: A CASE STUDY AT MTS PPMI ASSALAAM SUKOHARJO
}

\author{
Zainal Ariffin \\ MTS PPMI Assalaam Sukoharjo \\ Jl. Garuda Mas, Pabelan, Sukoharjo, Jawa Tengah 57102 \\ zaen_nur1@yahoo.com
}

\begin{abstract}
This article is a case study on exploring teachers' beliefs on teaching methodology in the 2013 curriculum and their application in language teaching. The type of the research is a case study. It is an in depth study of a particular situation. The object of the research is beliefs on teaching methodology in The 2013 Curriculum and their Applications in Language Teaching at MTs PPMI Assalaam Sukoharjo. The subjects of the research were English teachers of MTs PPMI Assalaam Sukoharjo. There were two males and two females teachers. There are three kinds of data sources, namely field note, interview, and document which were taken from informants, documentation, and events. The writer applied four techniques of collecting data, namely open ended questionnaire, observation, in-depth interview, and documentation. The data validity used triangulation method to eliminate bias. It used Miles and Huberman's model in analyzing the data. This study, there were found the EFL teachers' beliefs on teaching methodology in the 2013 curriculum and their application in the language teaching, namely learning objectives, syllabus, classroom management, teachers' role, students' role, instructional material and assessment. Besides, there were also found that there were some discrepancies found between EFL teachers' beliefs and their practices in classroom teaching. They were in the component of learning objective, syllabus, and classroom management. There are some factors contribute to these discrepancies, namely (1) the teachers' internal factors, (2) teachers' external factor. The last, there are some factors contribute to shape the EFL teachers' beliefs on the method of teaching English at MTs PPMI Assalaam Sukoharjo, namely (1) teachers' experience as language learners; (2) experience from teaching; (3) expectation from the school, parents, the government, and the local society; and (4) training.
\end{abstract}

Keywords: Teachers'beliefs, teaching methodology, the 2013 curriculum, application, language teaching

\section{ABSTRAK}

Artikel ini merupakan studi kasus pada eksplorasi keyakinan guru tentang metodologi pengajaran pada kurikulum 2013 dan penerapannya dalam pengajaran bahasa. Jenis penelitian ini adalah studi kasus. Ini adalah penelitian mendalam dari situasi tertentu. Objek penelitian adalah keyakinan pada metodologi pengajaran pada K-13 dan penggunaan mereka dalam pengajaran bahasa di MTS PPMI Assalaam Sukoharjo. Subjek penelitian adalah guru bahasa Inggris di MTs PPMI Assalaam Sukoharjo. Ada dua laki-laki dan dua guru perempuan. Ada tiga jenis sumber data, yaitu catatan lapangan, wawancara dan dokumen yang diambil dari informan, dokumentasi, dan peristiwa. Penulis menerapkan empat teknik dalam pengumpulan data, yaitu open-ended kuesioner, observasi, wawancara mendalam, 
dan dokumentasi. Validitas data yang digunakan adalah dengan metode triangulasi untuk menghilangkan bias. Penelitian ini menggunakan model Miles dan Huberman dalam menganalisis data. Hasil penelitian ini menunjukkan adanya keyakinan guru tentang metodologi pengajaran dalam kurikulum 2013 dan aplikasinya dalam pengajaran bahasa, antara lain tentang tujuan pembelajaran, silabus, pengaturan kelas, peran guru, peran siswa, materi pembelajaran, dan penilaian. Selain itu, juga ditemukan bahwa ada beberapa perbedaan yang ditemukan antara keyakinan guru dan praktik mereka dalam mengajar di kelas. Perbedaan tersebut berada di komponen tujuan pembelajaran, silabus, dan pengelolaan kelas. Ada beberapa faktor yang berkontribusi terhadap perbedaan ini, yaitu; (1) faktor internal guru, (2) faktor eksternal guru. Yang terakhir, ada beberapa faktor yang berkontribusi untuk membentuk keyakinan para guru pada metode pengajaran bahasa Inggris di MTs PPMI Assalaam Sukoharjo, yaitu (1) Pengalaman guru sebagai pembelajar Bahasa; (2) pengalaman mengajar; (3) harapan dari sekolah, orang tua, pemerintah, dan masyarakat setempat; dan (4) pelatihan.

Kata Kunci: Keyakinan guru, metodologi pengajaran, K-13, penggunaan, pengajaran bahasa

\section{INTRODUCTION}

The learning method is a method or the efforts made by teachers that teaching and learning process achieved by students in accordance with the purpose of learning objective. It is a method used by teachers to make contact with students during the learning takes place. It is very important so that the learning process seems fun and not bored, therefore the students are able to capture knowledge from educators easily.

At MTs PPMI Assalaam Sukoharjo, there are some unintended results of teaching learning although there are many methods used. There are also some facilities, for example, comfortable classroom, laboratory, and gratify surrounding. Although the method and the condition of environments are appropriate with the expectation, but some problems in teaching learning in the classroom appears. When teachers teach in classroom, some students sleep in the classroom. When teachers explain the lesson, they feel so difficult to make students understand about the materials. There are also some students going out the classroom and not coming back to the class, so not all students understand about the lesson of that day, as a result some of students get bad score when they face the examination. In addition, there are some teachers teaching monotonously, so students are bored in the class. Therefore teaching learning process in the classroom cannot run well as a result the most students do not understand material explained by teachers and get bed score when they face examination.

PPMI Assalaam is one of boarding schools in Central Java, Indonesia which has many alumni. They have become government officials, entrepreneurs and successful people in Indonesia. Besides, in PPMI Assalaam Sukoharjo, it serves many facilities in the teaching learning process. Moreover, most of teachers have been graduated from the university with high grade point average. Furthermore, the inputs of students are from many islands in Indonesia. Although this condition is like that, there are some problems found like sleeping in the class, going out the classroom and not coming back to the class, and etc. Based on the reasons above, the writer is interested to exploring teachers' beliefs on teaching methodology in the 2013 curriculum and their application in language teaching at MTs PPMI Assalaam Sukoharjo.

Teachers have a very important role in the success of learning. What they do in class is very influential on student success. Things that affect what teachers do in classroom are teachers' beliefs. They are very important for understanding and improving educational process. 
According to Richard and Lockhart (1994:105), they stated that the role of teacher in teaching learning are as facilitator, as classroom manager, as assessor as motivator and as planner.

In PPMI Assalaam Sukoharjo, most of teachers have been graduated from the university with high grade point average, namely; above 3.00. Even though, when teachers explain the lesson, they feel so difficult to make students understand about the materials. Moreover, there are some teachers teaching monotonously, so students are bored in the class. Based on the additional reasons above, the writer is interested to exploring teachers' beliefs on teaching methodology in the 2013 curriculum and their application in language teaching at MTs PPMI Assalaam Sukoharjo.

Teachers' beliefs play a very important role in classroom practices. According to Fauziati, (2015:53), she stated that; "Teachers" beliefs are very important for understanding and improving educational process. They play a very important role in classroom practices and in the professional growth of teachers. They guide teachers to adopt their teaching strategies for coping with their daily language teaching challenges. They can shape learners' learning environment, their motivation, and their learning achievement. Teachers' beliefs have some influences. They influence goals, procedures, materials, classroom interaction patterns, roles, their students, and the school they work in".

Pajares in Fauziati (2015:53) states that there are many different terms referring to teachers' beliefs, such as attitude, value, perspectives, and cognition BAK (beliefs, assumption, and knowledge), etc. Most definition of beliefs proposes that beliefs dispose or guide people's thinking and action. Moreover, Kagan defined teacher beliefs as "tacit, often unconsciously held assumptions about students, classroom, and the academic material to be taught".

Woods in Fauziati (2015:53) defined beliefs using his "BAK" model, which stands for beliefs, assumption, and knowledge; the model describes teacher decision-making process. Knowledge is something people hold as facts, which can be demonstrated (e.g. the black hole). Assumption is temporary fact that is held to be true (e.g. assuming someone taking your books). Beliefs are the accepted proposition that cannot be demonstrated, and people can have different beliefs. (e.g. disagreeing in language policies)

The success of teachers' teaching method depends on teachers' beliefs. According to Richards and Lockhart in Fauziati (2015:54), teachers' beliefs system are founded on the goals and values teachers hold on the content and process of teaching, and their understanding of the systems in which they work within it. These beliefs and values serve as underlying principles of the teachers' decision making and action, hence called teaching culture.

As Harste and Burke (1977) in Fauziati (2015) stated that teachers make decisions about classroom interaction in light of theoretical beliefs. They hold about teaching and learning. Teachers' beliefs influence their goals, procedures, material, classroom interaction patterns, their roles, their students, and the school they work in. They can be used as guide lines for teachers to adopt their classroom practice and to cope with daily teaching problem. They also influence teacher teaching attitude, teaching methods and teaching policy. Teachers who fail to explore their beliefs bring about unexpected consequences in the classroom and those who are willing to explore their beliefs can take a good advantage of the beliefs they hold to promote their teaching learning process in classroom. Therefore, the success of teachers' method of teaching depends on teachers' beliefs.

According to Bryan (2012) in Evans (2014:17-18) stated that research over the past three decades had resulted in a set of assumptions about the nature of teachers' beliefs that are widely accepted. These include: (1) beliefs are far more influential than academic knowledge in framing, analyzing and solving problems, and making teaching decisions, (2) some beliefs are more strongly held than others, resulting in "core" and "peripheral" beliefs, an individual's core 
beliefs may be more resistant to change, (3) beliefs do not exist independently of one another, but are arranged in an ecology, or an "internal architecture" of systems that have psychological importance to the individual (4) individuals may have competing belief sets about the same topic, (5) when one belief is changed, it is likely to affect other beliefs throughout the system, (6) some scholars posit that belief systems occur in "nests" or sets of beliefs, including core and peripheral beliefs about various principles that are linked or grouped together.

According to Munby (1984) in Evans (2014) solidified the importance of teacher beliefs to practice. Munby recognized that teachers are not likely to be convinced to adopt innovative teaching strategies based solely on scientific evidence from research studies. Rather, teachers will take on the important role of interpreting the innovation and evaluating its efficacy for their particular students. Munby asserted that importantly, part of a teacher's context which is evidently significant to adopting research findings or implementing curricula is what a teacher believes. Munby concluded that the participant teacher in his study, Ellen, had deep seated beliefs that guided her practice, namely (1) helping students cope with new information and learn independently; (2) increasing student confidence; and (3) helping students learn concepts in the earth science curriculum which she thought were valuable for their everyday lives. Ellen's orientation to teach was pragmatic rather than theoretical. Munby concluded that Ellen would review and filter new curriculum innovations for those that were resonate with her core beliefs.

According to Richards and Lockhart in Fauziati (2015:54), teachers' beliefs system are founded on the goals and values teachers hold on the content and process of teaching, and their understanding of the systems in which they work within it. These beliefs and values serve as underlying principles of the teachers' decision making and action, hence called teaching culture. Teacher beliefs systems are built up gradually over time and they are derived from different sources, namely (1) their own experience as language learner, (2) experience of what works best, (3) established practice, (4) personality factors, (5) education-based or researchbased principles, and (6) principles derived from an approach or method.

The previous study was written by Li LI (2012), concerning about belief construction and development: two tales of non-native English speaking student teachers in a Tesol programme. The study suggests that teacher education programmes shape and develop pre-service teachers' beliefs. A major contribution of this study is to argue that the development of student teachers' beliefs mirrored identity shifts of NNS student teachers in the programme; a finding which has the potential to inform the future design of language teacher education programmes. Data from interviews, micro-teaching and written reflections upon their teaching practice yielded a description of each participant's belief development. Findings suggest that various factors including the teacher education programme heavily shape and develop student teachers' beliefs. In the development of their beliefs, student teachers move through different views of themselves as teachers, negotiating a new identity.

Another previous study was conducted by Melketo (2012) concerning on exploring tensions between English teachers' beliefs and practices in teaching writing. The result shows that from the interviews, it was apparent that teachers' beliefs about teaching the writing process and appropriate writing strategies for enhancing and supporting the development of students' writing skill were constant. In the study, however, teachers' classroom practices did not always correspond to their beliefs. The reasons for a mismatch would seem to be highly complex, but there was evidence to suggest that teachers' ability to teach related to their beliefs was influenced mainly by contextual factors such as class time, students' expectations, teaching the test rather than teaching the subject and focusing on classroom management concerns.

Nhapulo's study (2013) presents teacher and learner beliefs and expectations about English language teaching and learning at a Mozambican university. The study shows that 
(1) Mozambican students and teachers have generally the same beliefs differing mainly in the frequency of their agreement and disagreement. (2) Students believe that, although there are new textbooks and dictionaries rooted in the Mozambican reality, there is still a lack of up-todate teaching material that fits the linguistic level of university students, as well as an effective syllabus and curriculum design that takes into consideration their beliefs, needs and cultural background. (3) Both teachers and students admit that there are authoritative and friendly teachers, and this has to do with Mozambican culture which is not egalitarian as such. Students also believe that teachers should be available in and outside the classroom environment, but the busy Mozambican turbo teachers are seldom available. (4) Advanced students are highly motivated to learn English, but they often lack self-confidence and do not receive sufficient reading strategy instruction applicable to their Bantu languages, Portuguese, the language of instruction in Mozambique, from which they could have acquired good reading skills. (5) Teachers believe that they have learnt English outside the formal setting, which means that students should look for extra English classes outside the university as well.

Siddiquee and Ikeda's study (2013) presents science teachers' beliefs on teaching and learning at secondary schools in Bangladesh. The results of the study have revealed that science teachers' belief regarding teaching and learning did not partition within a particular belief dimension. Teachers possessed direct transmission (traditional) belief regarding student role and classroom organization aspects of teaching and learning. On the other hand, the respondents' support of modern belief on teacher role, curriculum, and teaching style aspects of teaching and learning are stronger than that direct transmission belief. Analysis of interviews supported these findings. The study also revealed that teachers' belief did not vary in case of gender but formal education, teaching experiences and trainings were shown divergence.

Gonçalves, Azevedo, and Alves'study (2013) present about teachers' beliefs about teaching and learning: An Exploratory Study. The study aims to identify beliefs about teaching and learning within a group of Portuguese teachers according to their understanding of the nature of teaching, the nature of learning and the construction of their professional knowledge. Drawing on recent research concerning teachers' professional identity, reflexivity, and cultural narratives of teaching and learning, they present an exploratory study of Portuguese teachers' beliefs concerning teaching and learning, as part of their professional knowledge. The finding shows contradictions and ambiguities were detected in the teachers' perspectives. The ambiguities which detected in the teachers' answers indicate that normative discourses (technical and instrumental, assessment and accountability, standards and competences) contribute to shaping teacher beliefs about teaching and learning. However, the complexity of the teaching profession prompts the coexistence of other relevant discourses (care, responsibility, commitment).

Shim's study (2014) presents about a bourdieuian analysis: teachers' beliefs about English language learners' academic challenges. This study argues that teachers' beliefs that are linked to their socio-cultural backgrounds can delimit or enhance ELLs' academic lives, as those beliefs shape what teachers teach and what they see as a productive pedagogy in working with ELLs. The analysis indicates that tensions across teachers' beliefs, as well as within each teacher's set of beliefs, can serve as an opening to transform their perspectives towards more equitable pedagogical practice for ELLs.

Chu's study (2014) presents teachers' beliefs in teaching English for kids at a kindergarten: a case study of students from the department of applied English. The study results revealed that before and after teachings, there were no significant differences in teachers' beliefs between the aspects of English teaching (e.g. teaching resources and the preparation of lesson plan) and English learning (e.g. understanding of the kids' learning conditions). Inconsistent viewpoints in the beliefs of teacher-student interaction in class and curriculum planning were reported. 
Hongboontri and Keawkhong's study (2014) is school culture: teachers' beliefs, behaviors, and instructional practices. The finding showed that pattern of school cultures is practiced at Hope University's Language Institute A couple of teacher participants preferred individuality as they wanted to preserve their professional autonomy and their power and right to exercise their decisions made relating to their own instructional practices. More important, these findings urged not only the Director of the participated Language Institute but also education administrators and policymakers to pay serious attention to school culture. Their understanding of school culture could offer the basis for an expanded understanding of teacher quality and school success, one that considers several education outcomes together with data about what teachers actually think and do in the course of their work.

The second finding was about effects of school cultures have been in EFL Teachers at Hope University's Language Institute in Terms of Their Instructional Practices. It can be seen almost all these participants did centralize their teaching on their textbooks to help prepare students for examinations. In their teaching, these teachers mainly focused on discrete grammar points and translation (for Thai EFL teachers); the activities they implemented had little (or almost no) relation with the teaching content; seatwork exercises were heavily used; interaction between a teacher and students or among students themselves was scarce; and students had no opportunities to use English for actual communication. It also can be seen the report of the teaching practices of the EFL teachers in one Japanese high school whose culture was identified as routine/uncertain coincided with Kleinsasser's.

Mahmoudi, Jafari, and Ziyaei'sstudy (2015) is teachers' beliefs of effective teaching in the foreign language classroom: a study of nonnative EFL teacher. The study showed that novice Iranian EFL teachers feel more efficacious in applying instructional strategies at EFL class. They are efficacy to motivate and engage students to learn English not as high as their efficacy. Second, the teachers perceive their reading skill to be the most highly developed language skill and listening to be the language. The teachers report that their use of grammatically oriented strategies is lower than that of strategies. The important was the positive relationship between perceived level of language proficiency and sense. The teachers' perceived proficiency in language skills, the more efficacious.

Larenas, Hernandez, and Navarrete's study (2015) was a case study on EFL teachers' beliefs about the teaching and learning of English in public education. The result of the study shows that there are seven categories and six subcategories are presented in this section. The categories are: (1) the use of English in EFL lessons, (2) the teacher role, (3) the student role, (4) the teaching components. This category has got the following subcategories: (4.1.) materials and resources, (4.2.) EFL activities, (4.3.) learning aims, (4.4.) contents, (4.5.) teaching methodologies, and (4.6.) assessment. The next categories are: (5) the role of the teaching and learning context, (6) the role of the language curriculum, and (7) the relationship between the language curriculum and the course book contents. It also shows that beliefs are rooted in teachers' semantic memory as cognitive and affective constructs that hold different degrees of fixation depending on the professional, academic or personal experiences that shaped them. These participants do believe that effective English teaching requires aligning a series of components that influence and interact one another in the classroom. Some beliefs are not then static, they are very much influenced by what works well and unwell for teachers and they are practice-oriented in a bidirectional relationship, in which teachers try out their beliefs in their own pedagogical practices and give shape to other beliefs from those same practices.

This current study provides a brief overview of the importance of understanding the teachers' beliefs on teaching methodology in the 2013 curriculum and their application in language teaching. One of the most important contributions of research on teachers' beliefs is 
that the beliefs that teachers hold about teaching and learning influence their effective teaching in the classroom. They are the guidance of teacher's behavior and thinking, with ideas and knowledge formed to derive personal viewpoints and behavior. Beliefs not only affect teachers' perception and the management of classroom, but also play an important role in forming teaching objectives and teaching missions in the teaching learning process.

The current study presents exploring EFL teachers' beliefs on teaching methodology in the 2013 curriculum and their applications in language teaching at MTs PPMI Assalaam Sukoharjo. The current study aims (1) to investigate the EFL teachers' beliefs of English Teaching method at MTs PPMI Assalaam Sukoharjo, (2) to investigate whether there are some discrepancies between EFL teachers' beliefs and their practices in teaching, (3) to investigate factors contribute to these discrepancies between EFL teachers' beliefs and their practices in teaching, and (4) to investigate factors contribute to shape the EFL teachers' beliefs on the method of teaching English at MTs PPMI Assalaam Sukoharjo.

\section{RESEARCH METHOD}

This study is a case study research. It is a qualitative approach in which the investigator explores a real-life, contemporary bounded system (a case) or multiple bounded systems (cases) over time, through detailed, in-depth data collection involving multiple sources of information (e.g., observations, interviews, audiovisual material, and documents and reports), and reports a case description and case based themes. (Creswell, 2007:73)

The object of the research is beliefs on teaching methodology in the 2013 curriculum and their applications in language teaching at MTs PPMI Assalaam Sukoharjo.

This research was conducted at MTs PPMI Assalaam Sukoharjo. The subjects of the research were English teachers of MTs PPMI Assalaam Sukoharjo consisting of two males and two female teachers who have gone through five years of formal training at a university level; therefore, their proficiency level in English is at least upper intermediate or above.

There were three kinds of data sources. They were field note, interview, and document. The data of the research were all activities of the teachers taken from field note and observation coming informant, documentation and events.

To collect the research data, the writer applied four research techniques, namely open ended questionnaire, observation, in-depth interview, and documentation. In this research, it used Miles and Huberman's (1984:21-23) model. They are data collection, data reduction, data display, and conclusion (verification or drawing).

\section{FINDINGS AND DISCUSSION}

The description presents the EFL teachers' beliefs on teaching methodology in the 2013 curriculum and their practice in the classroom. The first belief is about learning objective. They believe that it is a description and statements of behavior which is expected to be achieved by students after learning takes place with the basic competencies. They assume that it is very important in order that the implementation of the teaching process can be directed and as a reference frame to fit the destination that has been specified at the beginning and before the implementation of teaching and in accordance with the basic competencies are planned. By conducting the observation at the teaching learning time and doing evaluation at the end of teaching they know the achievement of learning objective. The following is an example of the statement relating to learning objective;

"Learning objectives are some points to be achieved or behavior that can be done by the students on certain conditions and level of competence in teaching and learning."

(Adopted from Open-ended Questionnaire, 1a) 
The second belief is about syllabus. They believe that it was as a guide in teaching learning process. It is a set of lesson plans on a particular subject that includes standards of competence, basic competence, subject matter/learning, learning activities, indicators, and assessment, allocation of time and resources/materials. They consult with the board of MGMP, colleagues, and headmaster relating to the book which is used as well as using existing book that has given the school and use the online book PDF form. Moreover, they also look for other references from the bookstore. The following is an example of the statement relating to syllabus;

"Syllabus is a lesson plan on a particular subject that includes standards of competence, basic competence, the subject matter of learning, learning activities, indicators, assessment, allocation of time, and learning resources".

(Adopted from Open-ended Questionnaire, 2a)

The classroom management means that there is an effective classroom management. They assume that it is a set of teachers' activities to create and maintain the order of the classroom atmosphere conducive to support the learning process. There are some ways relating to classroom management, namely warm and enthusiastic, self discipline, varies and the emphasis on positive things. They stated that an effective learning is the learning process in which is not only focused on the results achieved learners, but what an effective learning process is able to provide a good understanding, intelligence, perseverance, opportunity and quality and can deliver behavioral change and apply it in their lives which is an achievement targets set in the plan. The following is an example of the statement relating to classroom management;

"Classroom management is an attempt by the teachers in order to create, conditioning classes as optimal as possible in order to create a class conducive to teaching and learning."

(Adopted from Open-ended Questionnaire, 3a)

They also assume that teacher's role is not only more than simply standing in front of a classroom but also lecturing. An effective teacher understands that teaching involves wearing multiple ways to ensure that the school day runs smoothly and all students receive a quality education. There are some teachers' roles, namely teachers as facilitator, controller, observer, and explainer. They involve students in their teaching activities, teachers act as facilitators in the teaching activities, so students play an active role. The following is an example of the statement relating to teacher' role;

'I'm as the facilitator, who can provide facilities that allow for fun in students' learning activities. Then, I'm also as mentors who guide students into mature adults. In addition, I'm as classroom manager and evaluator."

(Adopted from Open-ended Questionnaire, 4a)

Relating to students' role, they assume that students are responsible for their own success in the learning process. They should be actively involved in the learning process and should behave appropriately in a learning environment. There are some students' roles, namely as processor, performer, and listener. Students are already many active roles in teaching so that the teacher's role as a facilitator, as the curriculum in 2013 can already be seen. Students become active and they can cooperate with each other. Teachers are not the only source but facilitators who organize the conditions to enable the learning for students. The following is an example of the statement relating to students' role; 
"The roles are as learners have the primary task of learning, the students are responsible to their selves in the form of the ability to produce maximum achievement."

(Adopted from Open-ended Questionnaire, 5a)

They believe that instructional material is defined as content that conveys the essential knowledge and skills of a subject in the school curriculum through a medium or a combination of media for conveying information to a student. There are some instructional materials, namely printed material and unprinted material. The materials they convey are in accordance with book ranging from explanations and exercises there. In addition they also provide additional material from the internet. So it is in conformity with the existing curriculum or syllabus. The following is an example of the statement relating to instructional material;

"Learning material is essentially an integral part of the syllabus, namely planning, predictions and projections on what will be done during the learning activity."

(Adopted from Open-ended Questionnaire, 6a)

The last belief is about assessment. They assume that assessment is a series of activities to acquire, analyze, and interpret data about the process and the learning outcomes of students who performed in a systematic and continuous, so that into meaningful information in decision making. They believe that there are formative assessment and summative assessment. Assessments should suitable to the characteristics of the basic competencies, (1) skillsperformance, product tests, projects; (2) knowledge, written test; (3) attitude, observation sheets. The following is an example of the statement relating to assessment;

"Assessment is an attempt to obtain a variety of information on a regular basis, continuous and thorough about the process and the result of the growth and progress that has been achieved by students through learning activities."

(Adopted from Open-ended Questionnaire, 7a)

Besides the teachers' beliefs on teaching methodology in the 2013 curriculum, there are also some discrepancies found between EFL teachers' beliefs and their practices in classroom teaching. They are in the component of learning objective, syllabus, and classroom management. It can be seen that some teachers do not prepare learning objectives in the lesson plan before the implementation of teaching, there are limited variations in classroom setting and some of classroom management does not run well even and there are some shortcomings in its implementation. The following is an example of the statement relating to discrepancies between EFL teachers' beliefs and their practices in classroom teaching;

"In one year, we have to collect a learning tool in semester 1 and 2. Such devices include prota, promes and lesson plans. This program is expected to the implementation of learning in classroom run smoothly as planned. However, the activities of the board of PLP (educational services program) make different plans with the field so that we sometimes do not prepare the lesson plan before teaching in class.

(Adopted from the interview with Mrs. R on April 2016)

There are some factors contribute to shape the EFL teachers' beliefs on the English teaching method at MTs PPMI Assalaam Sukoharjo. They are (1) teachers' experience as language learners; (2) experience from teaching; (3) expectation from the school, parents, the government, and the local society; and (4) training. The following is an example of his 
statement relating to factors contributes to shape the EFL teachers' beliefs on the English teaching method;

"When I was at the school or college, I had seen how my teachers taught in the class. From what they had done, I follow the way they teach. In addition, I also developed the method which was more or less corresponding and change so much the better."

(Adopted from an interview with Mr. A on Tuesday, April 12th, 2016)

The last, there are some factors contribute to these discrepancies. They are (1) the teachers' internal factors; (2) teachers' external factor. The following is an example of statement relating to some factors contributes to these discrepancies coming from teachers' external factor;

"There are some problems in the teaching learning process, namely (1) the condition of the students' readiness in the class; (2) many activities done by students in outside of the class like the scout, mukhadhoroh, martial art, etc; (3) the awareness of students about the importance of study, because their parents are rich. These situation make some students are not ready to study in the class, sleepy, and little attention to the lesson."

(Adopted from an interview with Mr. S on Tuesday, April 12th, 2016)

\section{CONCLUSION}

Based on the findings and the explanation above, there are some conclusions. The first; the writer concluded those teachers' beliefs on some component of teaching methodology at MTs PPMI Assalaam Sukoharjo accordance with the theories by the expert, even though there are some discrepancies between their beliefs and their practice. The discrepancies are in the component of learning objective, syllabus, and classroom management. It can be caused by the internal and external factors. The second, there are some factors shape teachers' beliefs, the most factors influence the teachers' beliefs are trainings held by the foundation. The last conclusion is about factors of discrepancies between their beliefs and their practice. The most of the factors is caused by teachers external factor, namely the low of students' enthusiasm, an account of students in class is not proportional (more than 30 students), there is additional program outside of the class, namely; scout, martial art, mukhadhoroh, etc, and the position of schedule period in teaching, therefore, the teachers external factor are more that the teacher internal factors.

Teachers' beliefs about language learning affect everything that they do in the classroom, guiding and prompting classroom actions much more strongly than the use of a particular methodology or course book. It shows that teachers' pedagogical beliefs closely influence their instructional practices, decision-making in classroom and classroom interaction. Therefore, it should be known by the teachers that their beliefs about language learning teaching methodology are important for understanding and improving educational process.

\section{REFERENCES}

Creswell, John W. 2007. Qualitative Inquiry and Research Design: Choosing Among Five Approaches-2nd ed. London: Sage Publications Ltd.

Chu, Yu-wei. 2014. Teachers' Beliefs in Teaching English for Kids at a Kindergarten: A Case Study of Students from the Department of Applied English. English Language Teaching; Vol. 7, No. 10; 2014. ISSN 1916-4742 E-ISSN 1916-4750 Published by Canadian Center of Science and Education. 
Evans, Robert, Julie Luft \& Charlene Czerniak (Eds.), 2014. The Role of Science Teachers' Beliefs in International Classrooms. The Netherlands: Sense Publishers.

Fauziati, Endang. 2015. Teaching English As a foreign Language: Principle and practice. Surakarta: Era Pustaka Utama.

Gonçalves, Teresa N. R., Nair Rios Azevedo, \& Mariana Gaio Alves. 2013. Teachers' Beliefs about Teaching and Learning: An Exploratory Study. Educational Research Journal. 2013, vol. 2, N 1 University of Alicante.

Hongboontri, Chantarath \& Natheeporn Keawkhong. 2014. School Culture: Teachers'Beliefs, Behaviors, and Instructional Practices. Australian Journal of Teacher Education. Volume 39, Issue 5 Article 5, 201. 65-88

Larenas, Claudio Díaz, Paola AlarCón Hernandez, \& Mabel Ortiz Navarrete, 2015. A Case Study on EFL Teachers' Beliefs about the Teaching and Learning of English in Public Education. Received: 1 January 2013 / Accepted: 31 July 2014. ISSN: 1697-7467. Porta Linguarum 23, enero 2015 171-186.

Li LI. 2012. Belief Construction And Development: Two Tales Of Non-Native English Speaking Student Teachers In A Tesol Programme. Novitas-ROYAL (Research on Youth and Language), 2012, 6 (1), 33-58.

Mahmoudi, Halimeh Mohammad, Seyedeh Sara Jafari, \& Fatemeh Ziyaei. 2015. Teachers' Beliefs of Effective Teaching in the Foreign Language Classroom: A Study of Nonnative EFL Teacher. CJK Welfare \& Pharmascope Foundation. International Journal of Review in Life Sciences. ISSN 2231-2935. 5(6), 2015, 1-6.

Melketo, Tagesse Abo 2012. Exploring Tensions between English Teachers'Beliefs and Practices in Teaching Writing. The International HETL Review, Volume 2, 2012 (98-114). Retrieved on https://www.hetl.org/wp-content/uploads/2013/09/HETLReviewVolume2Article11. pdf.

Miles, M. B. \& Huberman, A. M. 1984. Qualitative Data Analysis: A Sourcebook of New Methods. California; SAGE publications Inc

Nhapulo, Marcos Abilio. 2013. Teacher and learner beliefs and expectations about English language teaching and learning at a Mozambican university. Africa focus - Volume 26, Nr. 2, 2013-pp. 81-109. Retrieved on http://www.afrikafocus.eu/file/29.

Nunan, David. 1989. Designing Task for Communicative Classroom. New York: Cambridge University Press.

Richard, Jack C. and Lockhart, C. 1994. Reflective Teaching in Second Language Classroom. Cambridge: Cambridge University Pres.

Shim, Jenna Min. 2014.A Bourdieuian Analysis: Teachers' Beliefs about English Language Learners' Academic Challenges. International Journal of Multicultural Education. 2014. Vol. 16, No. 1. Retrieved on http://ijme-journal.org/index.php/ijme/article/ viewFile/783/941.

Siddiquee, Muhammad Nur-E-Alam \& Hideo Ikeda. 2013. Science Teachers' Beliefs on Teaching and Learning at Secondary Schools in Bangladesh. GSE Journal of Education 2013 (ISSN 2289-3970) WorldConferences.net. 37-68. Retrieved on https://worldconferences.net/ journals/gse/GSE\%204\%20NUR\%20ELAM.pdf. 